\title{
FeM ANALYSiS In REDESIGN OF CONTINUOUS Profiling UNIT
}

\author{
KERAN, Z.; SKunCA, M.; MATH, M. \& MEDVED, T.
}

Abstract: The intention of this paper is to analyze the technology of continuous profiling of garage doors. According calculations process includes ten phases of continuous roll metal forming. Calculation of distance between two phases was regularly made according Shulze and was improved using FEM based software. The results that were obtained have been brought into comparison and presented in the paper.

Key words: Continuous profiling,FEM, Shulz, UBECO Profile
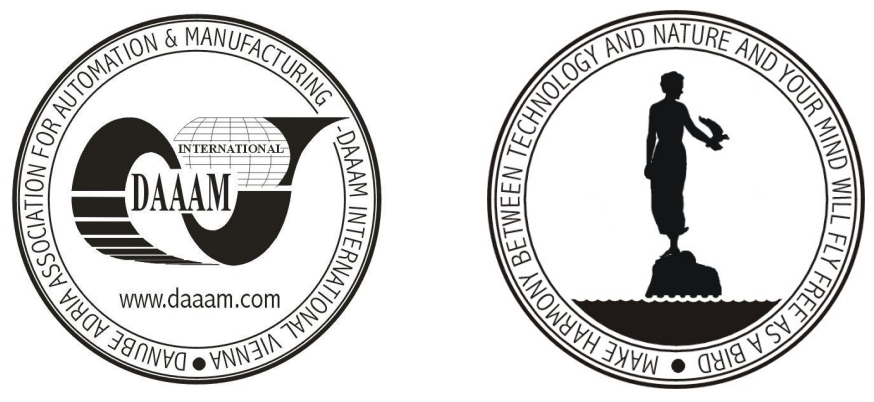

Authors' data: B.Sc. Keran, Z[denka]*; B.Sc. Skunca, M[arko]*; PhD. Math, M[iljenko]*; B.Sc. Medved, T[omislav], * Faculty of Mechanical Engineering and Naval Architecture, University of Zagreb, I. Lucica 5, 10000 Zagreb, Croatia, ** Medo-metal, Slavka Kolara 57, 10410 Velika Gorica, Croatia, zdenka.keran@fss.hr marko.skunca@fsb.hr, miljenko.math@fsb.hr,medo@medo-metal.hr

This Publication has to be referred as: Keran, Z.; Skunca, M.; Math, M. \& Medved, T. (2007). Fem Analysis in Redesign of Continuous Profiling Unit, Chapter 50 in DAAAM International Scientific Book 2007, B. Katalinic (Ed.), Published by DAAAM International, ISBN 3-901509-60-7, ISSN 1726-9687, Vienna, Austria DOI: $10.2507 /$ daaam.scibook.2007.50 